\title{
Performance of Different Sources of Livestock and Poultry Waste as Organic Manures on Growth and Yield of Fodder Maize (Zea mays)
}

\author{
Prasad Mithare*, U.S. Biradar, Pratik Jawarkar, M. Vaishali, Saste Ashwini, \\ Kamlakar and Avinash Karbari
}

Department of Livestock Farm Complex, Veterinary College, Bidar, Karnataka Veterinary Animal and Fisheries Sciences University, Bidar, India

*Corresponding author

\begin{abstract}
A B S T R A C T
Keywords

Bio-slurry, Forage,

FYM, Organic

material and silage

Article Info

Accepted:

22 October 2019

Available Online:

10 November 2019

The field experiment was conducted during kharif season of 2019at Fodder Production Unit of Livestock Farm Complex Department, Veterinary College Bidar. The aim of the experiment was to study the performance of different sources of livestock and poultry waste as organic manures on growth and yield of fodder maize. The experimental layout which was laid out in Randomized Block Design (RBD) with three replications. The results revealed that treatment $\mathrm{T}_{5}\left(\right.$ Poultry Manure $\left.12 \mathrm{t} \mathrm{ha}^{-1}\right)$ has performed significantlybetter than all other treatments namely, plant height $(206.47 \mathrm{~cm})$, number of leaves plant ${ }^{-1}(12.00)$, dry weight $(28.82 \mathrm{~g})$, leaf area index $(5.57)$, stalk length $(140.66 \mathrm{~cm})$, stalk girth $(13.47 \mathrm{~cm})$, number of cobs plant ${ }^{-1}$ (2.33), cob Length (16.35), cob girth (15.52), cob weight (85.35 g), green cob weight per $\mathrm{m}^{2}(3175.52 \mathrm{~g})$, green cob weight per $\mathrm{ha}^{-1}(3175.52 \mathrm{~g})$, green fodder yield plant ${ }^{-1}(195.75 \mathrm{~g})$, green fodder yield per $\mathrm{m}^{2}(3132.05 \mathrm{~g})$, green fodder yield ha ${ }^{-1}$ (31.32 t),dry fodder yield plant $^{-1}(41.22 \mathrm{~g})$, dry fodder yield per $\mathrm{m}^{2}(659.57 \mathrm{~g})$ and dry fodder yield ha ${ }^{-1}(6.60 \mathrm{t})$. Whereas, treatment $\mathrm{T}_{1}$ (Control) has performed poor among all the treatments. However, treatment $\mathrm{T}_{4}$ (Sheep Manure $12 \mathrm{t} \mathrm{ha}^{-1}$ ), $\mathrm{T}_{9}$ (Fermented Bio-Slury [Dung + Urine (1:1)] Soil Application $20 \mathrm{t} \mathrm{ha}^{-1}$ and Foliar Spray (10\%) @ 15, 30 \& 45 DAS) and $\mathrm{T}_{8}\{$ Fresh Bio-Slury [Dung + Urine (1:1)] $\}$ Soil Application $20 \mathrm{t} \mathrm{ha}^{-1}$ and Foliar Spray (10\%)@15,30 \& 45 DAS) were statistically at par with treatment $\mathrm{T}_{5}$ (Poultry Manure $\left.12 \mathrm{tha}^{-1}\right)$, respectively.
\end{abstract}

\section{Introduction}

Animal husbandry plays an important role in livelihood security and economic sustenance of farmers, especially in rainfed areas. As per $20^{\text {th }}$ Livestock Census of 2019, the total livestock population in India was 535.78 million in country showing an increase of
$4.6 \%$ over livestock census 2012. Karnataka is the $9^{\text {th }}$ largest state in cattle and buffalo population in the country, accounting for 29 million and it is $4.70 \%$ of the total population as per the latest Livestock Census, 2019GOI, DAHD 2019. The increasing population and diversified food and fodder requirement of the country is expanding at faster rate, enhancing 
food production for future years is very challenging. The growth of animal husbandry is linked with production, productivity and quality of forages. India inhabits $15 \%$ of world livestock on $2 \%$ geographical area with $5.23 \%$ cultivated fodder area. The fodder production in the country is not sufficient to meet the requirements; also the forages offered are mostly of poor quality. Present availability of green fodder is 462 million tonnes and dry fodder is 394 million tones and contribution of crop residue, cultivated fodder and grasslands is 54, 28 and $18 \%$ respectively. Currently, India is deficit by $35.6 \%$ in green fodder and $10.95 \%$ in dry fodder and $44 \%$ concentrate feed. This gap in demand and supply may further rise due to consistent growth of livestock population at the rate of $1.23 \%$ in the coming years and the demand of green fodder will rise to 1012 million tonnes by the year 2050. To meet out the deficit, green forage supply has to rise at $1.69 \%$ annually Rakesh Kumar 2016.Maize (Zea mays) is an ideal forage crop grown throughout the year. It is quick growing, high yielding and provides palatable nutritious forage which can be fed at any stage of growth without any risk to animals. Maize produces good quality herbaceous fodder with high digestibility. On an average, it contains $9-10 \%$ crude protein, $60-64 \%$ neutral detergent fibre, $38-41 \%$ acid detergent fibre, $28-30 \%$ cellulose and $23-25 \%$ hemi cellulose on dry matter basis when harvested at milk to early-dough stage. It can be fed as green or dry and makes excellent silage (Kumar et al., 2012). FYM is the principle source of organic matter in our country and it is a source of primary, secondary and micronutrients to the plant growth. It is a constant source of energy for heterotrophic microorganisms, help in increasing the availability of nutrient and crop produce quality. The entire amount of nutrients present in farmyard manure is not available immediately but about $30 \%$ of nitrogen, 60 to $70 \%$ of phosphorus and $70 \%$ of potassium are available to the first crop, while remaining amount of nutrients will be available to succeeding crop Hussain et al., (2019). The application of FYM also enhanced the availability of plant nutrient present in soil, while FYM is a store house of nutrient, which contains all essential plant nutrients Nawab et al., (2011). Vermicompost is an excellent base for the establishment of beneficial free living and symbiotic microbes. Application of vermicompost increases the total microbial population of nitrogen fixing bacteria that convert nutrient in soil into plant available form. Poultry litter is a mixture of manure and bedding materials, and it has been used successfully as an alternative plant nutrient source to inorganic fertilizer for the cultivation of numerous economically important crops, including maize, cotton, and pasture Kingery et al., (1993), Moss et al., (2001), Adeli et al., (2007), Mosquera et al., (2008). The use of poultry litter as a source of nutrients on agricultural lands is a safe and environmentally friendly way of disposing of their waste Hirzel et al., (2007). Poultry manure improves biological activities, soil tilth and soil chemical properties Michael and George, 2008. Superiority of poultry manure was also reported by Chandrasekhar et al., (2000) and Saranappa et al., (2002) showed $7.62 \%$ increase in seed yield of maize with the application of poultry manure.Bio-slurry is a mixture of (Dung + Urine) obtained from the livestock shed, which is collected in the digester tank. The composition of the bioslurry can consist of $93 \%$ water and $7 \%$ of dry matter, of which $4.5 \%$ is organic matter and $2.5 \%$ is non-organic matter. Although bioslurry contains higher amount of phosphorus, potassium, zinc, iron, manganese and copper, which is limited factor in many soils. Bioslurry with the dose of 10 to 20 tons $\mathrm{ha}^{-1}$ in irrigated areas and 5 to 10 tonsha $^{-1}$ in rainfed crops can show significant increase in yields. Indeed, bio-slurry increases crop revenues by 25\% on average Maria et al., (2014). The 
effects of bio-slurry application are comparable to the effects of the application of chemical fertilizers. As such, bio-slurry can be a serious alternative to chemical fertilizers (Warnars et al., 2013). Use of the slurry inhibits disease and increase yields (Liu et al., 2008).

\section{Materials and Methods}

The field experiment was conducted during kharif season of 2019 at Fodder Production Unit of Livestock Farm Complex Department, Veterinary College Bidar. The experiment site lies between $17.86^{\circ} \mathrm{N}$ latitude, $77.47^{\circ} \mathrm{E}$ Longitude and 710 meters altitude. The climate of the experimental location is characterized by warm and moderate humid weather during rainy season. The rainy season starts from second week of June to midOctober with mean temperature of $19.82^{\circ} \mathrm{C}$. The soil of the experimental site was sandy loam in texture having a $\mathrm{pH}(6.8), \mathrm{EC}(0.346$ $\mathrm{dSm}^{-1}$ ), organic carbon $(0.58 \%)$, available $\mathrm{N}$ $\left(310 \mathrm{~kg} \mathrm{ha}^{-1}\right), \mathrm{P}\left(20.16 \mathrm{~kg} \mathrm{ha}^{-1}\right), \mathrm{K}(301 \mathrm{~kg}$ $\left.\mathrm{ha}^{-1}\right), \mathrm{S}$ (14.70 ppm) Zn (0.50 ppm), Fe (4.61), $\mathrm{Mn}(1.80 \mathrm{ppm})$ and $\mathrm{Cu}(0.18 \mathrm{ppm})$ during the experimental season. The experiment was laid down in randomized block design (RBD) with 9 treatments and 3 replications. The sowing was carried out in fodder production unit on $18^{\text {th }}$ July 2019 , at a spacing of $30 \times 10 \mathrm{~cm}$. The control treatment was fertilized with recommended dose of NPK 80:40:30 kg ha ${ }^{-1}$ was applied. The (100\%) full dose phosphorus and potassium, whereas, (50\%) of nitrogen was applied at the time of planting as basal dose and remaining nitrogen was applied as top dressing at knee height stage. Irrigation was scheduled at 8-10 days interval during vegetative growth stage; however other normal cultural practices were followed timely as hand weeding at 20 DAS and 40 DAS, respectively. One quadrate $\left(\begin{array}{lll}1 & \mathrm{~m}^{2}\end{array}\right)$ was harvested in every plot for the determination of results and data was subjected to statistical analysis separately by using analysis of variance technique. The difference among treatment means was compared by using least significant difference test at 5\% probability levels. The treatment consisted of $\mathrm{T}_{1}$ : Control (RDF 80:40:30 Kg NPK ha $\left.{ }^{-1}\right), T_{2}:$ FYM (16 t $\left.\mathrm{ha}^{-1}\right), \mathrm{T}_{3}$ : Vermicompost $\left(12 \mathrm{tha}^{-1}\right), \mathrm{T}_{4}$ :Sheep Manure (12 $\left.\mathrm{t} \mathrm{ha}^{-1}\right), \mathrm{T}_{5}$ : Poultry Manure (12 t $\mathrm{ha}^{-1}$ ), $\mathrm{T}_{6}$ : Fresh Bio Slurry [Dung + Urine (1:1)] Soil Application $20 \mathrm{t} \mathrm{ha} \mathrm{ha}^{-1}, \mathrm{~T}_{7}$ : Fermented Bio-Slurry [Dung + Urine (1:1)] Soil Application $20 \mathrm{t} \mathrm{ha}^{-1}, \mathrm{~T}_{8}$ : Fresh Bio-Slurry [Dung + Urine (1:1)] Soil Application 20 $\mathrm{t} \mathrm{ha}^{-1}$ and Foliar Spray (10\%) @ 15, 30 and 45 DAS, $T_{9}$ : Fermented Bio-Slury $\{$ Dung + Urine (1:1) \} Soil Application $20 \mathrm{t} \mathrm{ha}^{-1}$ and Foliar Spray (10\%)@ 15, 30 and 45 DAS.

\section{Results and Discussion}

\section{Growth attributes}

\section{Plant height (cm)}

Plant height is the main yield component especially in fodder crops and it indicates the influence of various nutrients uptake on plant metabolism and vigor. Significantly maximum plant height $(49.25 \mathrm{~cm}),(146.91 \mathrm{~cm})$ and $(206.47 \mathrm{~cm})$ were recorded in treatment $\mathrm{T}_{5}$ at 20, 40 and 60 DAS. While minimum plant height $(30.08 \mathrm{~cm}),(123.82 \mathrm{~cm})$ and $(160.09$ $\mathrm{cm}$ ) were recorded in treatment $\mathrm{T}_{1}$. However, treatment $T_{9}$ and $T_{8}$ was statistically at par with treatment $\mathrm{T}_{5}$ at $20 \mathrm{DAS}$, whereas, $\mathrm{T}_{9}$ and $\mathrm{T}_{4}$ was found statistically at par with treatment $\mathrm{T}_{5}$ at 40 and $60 \mathrm{DAS}$, respectively (Table 1 and Fig. 1).

\section{Number of leaves plant ${ }^{-1}$}

The observations on number of leaves plant ${ }^{-1}$ was recorded significant difference between the treatments. The maximum number of leaves plant ${ }^{-1}(8.00),(10.00)$ and (12.00) were recorded in treatment $\mathrm{T}_{5}$ Poultry Manure $(12 \mathrm{t}$ 
$\mathrm{ha}^{-1}$ ) at 20, 40 and 60 DAS. While minimum number of leaves plant ${ }^{-1}(6.00),(8.00)$ and (10.00) were recorded in treatment $\mathrm{T}_{1}$ (Control). However, treatment $\mathrm{T}_{9}$ and $\mathrm{T}_{8}$ was statistically at par with treatment $\mathrm{T}_{5}$ at $20 \mathrm{DAS}$, whereas, treatment $T_{9}$ and $T_{4}$ was statistically at par with treatment $\mathrm{T}_{5}$ at 40 and $60 \mathrm{DAS}$, respectively (Table 1 and Fig. 1).

\section{Plant dry weight (g)}

The observations regarding plant dry weight revealed significant difference between the treatments. Highest plant dry weight $(2.16 \mathrm{~g})$, $(17.02 \mathrm{~g})$ and $(28.82 \mathrm{~g})$ were recorded in treatment $\mathrm{T}_{5}$ Poultry Manure $\left(12 \mathrm{t} \mathrm{ha}^{-1}\right)$ at 20 , 40 and 60 DAS. While, lowest plant dry weight $(0.99 \mathrm{~g}),(8.48 \mathrm{~g})$ and (17.84) were recorded in treatment $\mathrm{T}_{1}$ (Control).However, treatment $\mathrm{T}_{9}$ and $\mathrm{T}_{8}$ was statistically at par with treatment $\mathrm{T}_{5}$ at $20 \mathrm{DAS}$, whereas, treatment $\mathrm{T}_{9}$ and $\mathrm{T}_{4}$ was statistically at par with treatment $\mathrm{T}_{5}$ at 40 DAS. Similarly, treatment $\mathrm{T}_{4}$ and $\mathrm{T}_{9}$ was statistically at par with treatment $\mathrm{T}_{5}$ at 60 DAS, respectively (Table 2 and Fig. 2).

\section{Leaf Area Index}

Leaf Area Index is the main yield component in fodder crops and indicates influence of various nutrients uptake on plant metabolism and vigor. Significantly highest leaf area index (1.86), (3.78) and (5.57) were recorded in treatment $\mathrm{T}_{5}$ at 20, 40 and 60 DAS. While minimum leaf area index (1.59), (2.82) and (4.68) were recorded in treatment $\mathrm{T}_{1}$ However, treatment $T_{9}$ and $T_{4}$ was statistically at par with treatment $\mathrm{T}_{5}$ at 20 and 40DAS, whereas, $\mathrm{T}_{9}$ and $\mathrm{T}_{8}$ was statistically at par with treatment $\mathrm{T}_{5}$ at 40 and 60 DAS, respectively (Table 2 and Fig. 2).

\section{Crop growth rate $\left(\mathrm{g} \mathrm{m}^{-2} \mathrm{day}^{-1}\right)$}

Highest CGR (0.1078) and (0.7435) were recorded in treatment $T_{5}$ at $0-20$ and $20-40$
DAS. Whereas, highest CGR (0.6196) at 4060 DAS was recorded in treatment $\mathrm{T}_{3}$. While lowest CGR (0.0495) and (0.3745) were recorded in treatment $\mathrm{T}_{1}$ at $0-20$ and $20-40$ DAS. Similarly lowest CGR (0.4311) was recorded in treatment $T_{2}$ at 40-60 DAS.

However, treatment $T_{9}$ and $T_{8}$ was statistically at par with treatment $T_{5}$ at 0-20 DAS, whereas treatment $T_{9}$ and $T_{4}$ was statistically at par with treatment $\mathrm{T}_{5}$ at 20-40 DAS. Similarly, treatment $\mathrm{T}_{5}$ and $\mathrm{T}_{6}$ was statistically at par with treatment $\mathrm{T}_{3}$ at 40-60 DAS, respectively (Table 3 and Fig. 3).

\section{Relative growth rate $\left(\mathrm{g} \mathrm{g}^{-1}\right.$ day $\left.^{-1}\right)$}

Highest RGR (0.0482) and (0.0170) was observed in treatment $\mathrm{T}_{4}$ and $\mathrm{T}_{3}$ at 20-40and 40-60 DAS. While lowest RGR (0.0408) and $(0.0099)$ was in treatment $\mathrm{T}_{3}$ and $\mathrm{T}_{9}$.However, treatment $T_{9}$ and $T_{1}$ was statistically at par with treatment $\mathrm{T}_{4}$ at 20-40 DAS, whereas treatment $T_{1}$ and $T_{6}$ was statistically at par with treatment $\mathrm{T}_{3}$ at 40-60 DAS, respectively (Table 3 and Fig. 3).

\section{Stalk length $(\mathrm{cm})$ and Stalk girth $(\mathrm{cm})$}

The stalk length and stalk girth shown significant difference between the treatments. The highest stalk length $(11.53 \mathrm{~cm}),(79.50$ $\mathrm{cm}),(140.66 \mathrm{~cm})$ and highest stalk girth $(4.88$ $\mathrm{cm}),(9.87 \mathrm{~cm}),(13.47 \mathrm{~cm})$ were recorded in treatment $\mathrm{T}_{5}$ at 20, 40 and 60 DAS. While lowest stalk length $(8.18 \mathrm{~cm}),(46.83 \mathrm{~cm})$, $(84.70 \mathrm{~cm})$ and lowest stalk girth $(3.16 \mathrm{~cm})$, $(6.63 \mathrm{~cm}),(8.53 \mathrm{~cm})$ were recorded in treatment $\mathrm{T}_{1}$. However, treatment $\mathrm{T}_{9}, \mathrm{~T}_{4}, \mathrm{~T}_{8}$ and $\mathrm{T}_{6}$ were statistically at par with treatment $\mathrm{T}_{5}$, respectively (Table 4 and Fig. 4).

\section{Yield attributes}

The minimum number of days to $50 \%$ Tasseling was observed in treatment $\mathrm{T}_{5}(55.66$ 
days) followed by $\mathrm{T}_{9}$ (57.33 days), $\mathrm{T}_{7}$ (57.66 days) and $\mathrm{T}_{4}$ (58.33 days). While maximum number of days to $50 \%$ tasseling was observed in treatment $\mathrm{T}_{1}(65.66$ days) respectively. Similarly the observations regarding yield attributes are being presented and were observed significant difference between the treatments. The maximum yield attributes viz., number of cobs plant ${ }^{-1}$ (2.33), cob girth (15.52 $\mathrm{cm})$, cob weight plant $^{-1}(85.35 \mathrm{~g})$, cob yield per $\mathrm{m}^{2}(3175.52 \mathrm{~g})$, cob yield $\left(31.75 \mathrm{t} \mathrm{ha}^{-1}\right)$ was recorded in treatment $\mathrm{T}_{5}$. While minimum number of cobs plant ${ }^{-1}(1.00)$, cob girth (10.81 $\mathrm{cm})$, cob weight plant $^{-1}(45.12 \mathrm{~g})$, cob yield per $\mathrm{m}^{2}$ (721.86 g), cob yield $\left(7.21 \mathrm{t} \mathrm{ha}^{-1}\right)$ was recorded in treatment $T_{1}$. However, treatment $\mathrm{T}_{4}$ and $\mathrm{T}_{9}$ was statistically at par with treatment $\mathrm{T}_{5}$, respectively (Table 5 and Fig. 5).

\section{Yield}

Fodder maize had a significant effect on the yield with different sources of livestock and poultry waste as organic manure. The observations regarding yield attributes are being presented and were observed significant difference between the treatments. The highest green fodder yield plant ${ }^{-1}(195.75 \mathrm{~g})$, green fodder yield per $\mathrm{m}^{2}$ (3132.05 $\left.\mathrm{g}\right)$, green fodder yield $\left(31.32 \mathrm{t} \mathrm{ha}^{-1}\right)$, dry fodder yield plant ${ }^{-1}$ $(41.22 \mathrm{~g})$, dry fodder yield per $\mathrm{m}^{2}(659.57 \mathrm{~g})$, dry fodder yield $\left(6.60 \mathrm{t} \mathrm{ha}^{-1}\right)$ was observed in treatment $\mathrm{T}_{5}$.

While lowest green fodder yield plant $^{-1}$ $(135.81 \mathrm{~g})$, green fodder yield per $\mathrm{m}^{2}(2173.06$ $\mathrm{g}$ ), green fodder yield $\left(21.73 \mathrm{t} \mathrm{ha}^{-1}\right)$, dry fodder yield plant ${ }^{-1}(26.52 \mathrm{~g})$, dry fodder yield per $\mathrm{m}^{2}(424.37 \mathrm{~g})$, dry fodder yield (4.24 $\mathrm{t} \mathrm{ha}^{-1}$ ) was recorded in treatment $\mathrm{T}_{1}$. However treatment $\mathrm{T}_{4}$ and $\mathrm{T}_{9}$ was statistically at par with treatment $T_{5}$ with respect to all yield attributes, whereas, dry fodder yield $\mathrm{ha}^{-1}$ treatment $T_{9}$ and $T_{8}$ was found statistically at par with treatment $T_{5}$, respectively (Table 6 and Fig. 6).

\section{Growth attributes}

The results revealed that Plant height $(\mathrm{cm})$, Number of leaves plant ${ }^{-1}$, Plant dry weight (g), Leaf Area Index, Crop growth rate $\left(\mathrm{g} \mathrm{m}^{-2}\right.$ day $\left.^{-1}\right)$, Relative growth rate $\left(\mathrm{g} \mathrm{g}^{-1}\right.$ day $\left.^{-1}\right)$, Stalk Length $(\mathrm{cm})$ and Stalk girth $(\mathrm{cm})$ significant difference between the treatments at different intervals. Plant height is the main yield component mainly in fodder crops and indicates the influence of various nutrients uptake on plant metabolism and vigor. Number of leaves plant ${ }^{-1}$ may have helped in increasing the photosynthetic area for photosynthesis in plant. In maize plant the effect on number of leaves plant ${ }^{-1}$ production at all the growth stages was significant. Estimation of leaf area is an essential component of plant growth analysis and evapo-transpirational studies. Leaf area is important for crop light interception and therefore has a large influence on growth Boote et al., (1988), transpiration Enoch and Hurd (1979) and growth rate Leith et al., (1986). Leaf area production is essential for energy transference and dry matter accumulation processes in crop canopies. It is also useful in the analysis of canopy architecture as it allows determination of leaf area index, which is important for light interception, radiation use efficiency, plant growth, etc. The increase in plant dry weight (g) might be due to more assimilatory surface leading to higher dry matter production coupled with effective translocation and distribution of photosynthates from source to sink.

The percentage increase in CGR and RGR may be due to prevalence of optimum temperature coupled with less humidity at the growth stage and also application of organic manures which helps in easy availability of phosphorus and might be due to synergistic action of organisms which increased the phosphorus uptake. Abubakar and Ali (2018) 
reported that nitrogen influences plant height by affecting cell size, leading to rapid elongation of the internodes and consequently, the final plant height. Similarly leaves are the main photosynthetic organs of the plant, having less leaf number could result in the reduction of assimilates produced and partitioned to the grain Johnson et al., 2008.

Plant leaves number in all the weeks increases irrespective of the rate of PM, CD and NPK. NPK has the highest leave number as observed in week 4 followed by PM, and CD which also explains the reason behind the significant difference in leave number among the treatments. However, plants having PM and $\mathrm{CD}$ showed higher biomass compared to the control of the local variety. The organic manures and chemical fertilizers which were supplied as essential nutrition at initial establishment stage recorded the best results for the measured variables like height of the plant, width of the stem, dry weight of the shoots and roots.

The results of the experiment confirm the findings of Gonzalez et al., (2001). Similarly Materechera and Salagae (2002) reported higher plant height of maize could be achieved with the application of chicken and cattle manure. Poultry manures contains higher amount of essential nutrients and abruptly fulfil plant nutrients demand and also improve soil properties that can ultimately help in settling of nutrients in soil for a long period of time, highest plant height were obtained from treatment 6 having Poultry Manure and Humic Acid applied at 12.5 tons and $1 \mathrm{~kg} \mathrm{ha}^{-1}$ (Hussain et al., 2018).

However, we can state here is that bio-slurry is not only rich in mineral and organic dry matter, but also rich in nutrients like N, P, K, $\mathrm{Ca}, \mathrm{Mg}, \mathrm{Fe}, \mathrm{Mn}$, organic matter, different amino acids and metals like copper and zinc. There seems to be a good match between soil $\mathrm{N}$ supply and plant $\mathrm{N}$ demand of liquid bio- slurry which boosts crop vigor Oppenoorth $e t$ al., (2014). Similar findings are also reported by Warnars (2012).

\section{Yield attributes}

The findings of growth attributes namely; number of cobs plant ${ }^{-1}$, cob girth $(\mathrm{cm})$, cob weight plant $^{-1}(\mathrm{~g})$, cob yield per $\mathrm{m}^{2}(\mathrm{~g})$, cob yield $\left(\mathrm{t} \mathrm{ha}^{-1}\right)$, green fodder yield $\left(\mathrm{t} \mathrm{ha}^{-1}\right)$ and dry fodder yield $\left(\mathrm{t} \mathrm{ha}^{-1}\right)$ are being presented and were observed significant difference between the treatments at different intervals.

This might be due to genetic ability of the variety attributed to higher biomass accumulation coupled with effective translocation and distribution of photosynthates from source to sink, which in turn resulted into elevated stature of yield attributes.

The probable reason for recording higher yield under treatment with Poultry Manure $(12 \mathrm{t}$ $\left.\mathrm{ha}^{-1}\right)$, followed by Sheep Manure $\left(12 \mathrm{t} \mathrm{ha}^{-1}\right)$, and treatment with Fermented Bio-Slury [Dung + Urine (1:1)] Soil Application $20 \mathrm{t} \mathrm{ha}^{-1}$ and Foliar Spray (10\%) @ 15, 30 and 45 DAS was statistically at par among the treatments. Badu et al., (2012) reported that fodder yield is a function of genetic as well as the environmental factors, which plays a vital role in plant growth and development and ultimately contributed to fodder yield.

Statistically the maximum green forage yield $\left(74.67 \mathrm{t} \mathrm{ha}^{-1}\right)$ was observed in $\mathrm{T}_{2}(\mathrm{~N}: \mathrm{P} 2 \mathrm{O} 5$ $150: 60 \mathrm{~kg} \mathrm{ha}^{-1}$ ) while the minimum green forage yield of $\left(38.13 \mathrm{t} \mathrm{ha}^{-1}\right)$ in untreated treatment $\mathrm{T}_{1}$ (control). Next to the treatment $\mathrm{T}_{2}, \mathrm{~T}_{6}$ (N: P2O5 112:45+ FYM $1000 \mathrm{~kg} \mathrm{ha}^{-1}$ ) and $\mathrm{T}_{5}\left(\mathrm{~N}: \mathrm{P}_{2} \mathrm{O}_{5}\right.$ 112:45+ Poultry manure 750 $\mathrm{kg} \mathrm{ha}^{-1}$ ) were statistically at par with each other and gave significantly higher green forage yield of 70 and $69 \mathrm{t} \mathrm{ha}^{-1}$, respectively compared to all other treatments. 
Table.1 Performance of different sources of livestock and poultry waste as organic manures on growth and yield of fodder maize

\begin{tabular}{|c|c|c|c|c|c|c|c|}
\hline & Treatments & $\begin{array}{c}\text { Plant height } \\
\text { (cm) } \\
20 \text { DAS }\end{array}$ & $\begin{array}{l}\text { Plant } \\
\text { height } \\
(\mathrm{cm}) \\
40 \text { DAS }\end{array}$ & $\begin{array}{l}\text { Plant } \\
\text { height } \\
(\mathrm{cm}) \\
60 \text { DAS }\end{array}$ & $\begin{array}{l}\text { No. of leaves } \\
\text { plant }^{-1} \\
20 \text { DAS }\end{array}$ & $\begin{array}{l}\text { No. of leaves } \\
\text { plant }^{-1} \\
40 \text { DAS }\end{array}$ & $\begin{array}{l}\text { No. of } \\
\text { leaves } \\
\text { plant }^{-1} \\
\text { 60 DAS }\end{array}$ \\
\hline $\begin{array}{l}\mathrm{T} \\
1\end{array}$ & Control (RDF 80:40:30 Kg NPK ha ${ }^{-1}$ ) & 30.08 & 123.82 & 160.09 & 6.00 & 8.00 & 10.00 \\
\hline $\begin{array}{l}\mathbf{T} \\
2\end{array}$ & FYM $\left(16 \mathrm{t} \mathrm{ha}^{-1}\right)$ & 42.93 & 127.28 & 166.02 & 6.66 & 8.50 & 10.50 \\
\hline T & Vermicompost (12 t ha $\left.{ }^{-1}\right)$ & 43.50 & 135.58 & 175.74 & 7.00 & 8.67 & 10.67 \\
\hline T & Sheep Manure (12 t ha ${ }^{-1}$ ) & 45.20 & 141.70 & 187.06 & 7.33 & 9.50 & 11.50 \\
\hline $\begin{array}{l}\mathbf{T} \\
5\end{array}$ & Poultry Manure (12 $\left.\mathrm{t} \mathrm{ha}^{-1}\right)$ & 49.25 & 146.91 & 206.47 & 8.00 & 10.0 & 12.00 \\
\hline $\begin{array}{l}T \\
6\end{array}$ & $\begin{array}{c}\text { Fresh Bio-Slury \{Dung + Urine (1:1)\} Soil } \\
\text { Application } 20 \mathrm{t} \mathrm{ha}^{-1}\end{array}$ & 48.46 & 133.85 & 174.34 & 7.50 & 8.17 & 10.17 \\
\hline $\begin{array}{l}\text { T } \\
7\end{array}$ & $\begin{array}{l}\text { Fermented Bio-Slury \{Dung + Urine (1:1)\} } \\
\text { Soil Application } 20 \mathrm{t} \mathrm{ha}^{-1}\end{array}$ & 47.36 & 137.72 & 179.81 & 7.16 & 8.50 & 10.50 \\
\hline $\begin{array}{l}\mathbf{T} \\
8\end{array}$ & $\begin{array}{c}\text { Fresh Bio-Slury }\{\text { Dung + Urine (1:1) }\} \text { Soil } \\
\text { Application } 20 \mathrm{t} \mathrm{ha}^{-1} \text { andFoliar Spray }(10 \%) \\
\text { @ } 15,30 \& 45 \mathrm{DAS}\end{array}$ & 48.61 & 141.00 & 184.97 & 7.66 & 8.33 & 10.83 \\
\hline $\begin{array}{l}\text { T } \\
9\end{array}$ & $\begin{array}{c}\text { Fermented Bio-Slury }\{\text { Dung + Urine (1:1)\} } \\
\text { Soil Application } 20 \mathrm{t} \mathrm{ha}^{-1} \text { andFoliar Spray } \\
(10 \%) @ 15,30 \text { \& } 45 \text { DAS }\end{array}$ & 48.73 & 142.41 & 193.64 & 7.83 & 9.50 & 11.67 \\
\hline & F-test & $\mathbf{S}$ & $\mathbf{S}$ & $\mathbf{S}$ & $\mathbf{S}$ & $\mathbf{S}$ & $\mathbf{S}$ \\
\hline & C.D. $(p=0.05)$ & 10.00 & 5.29 & 5.28 & 0.89 & 0.58 & 0.56 \\
\hline & CV $(\%)$ & 12.87 & 2.24 & 1.69 & 7.08 & 3.80 & 2.98 \\
\hline & S.Ed. $( \pm)$ & 4.72 & 2.49 & 2.49 & 0.42 & 0.27 & 0.26 \\
\hline & $\operatorname{SEm}( \pm)$ & 3.34 & 1.76 & 1.76 & 0.30 & 0.19 & 0.19 \\
\hline
\end{tabular}

Note: S (Significant), NS (Non-Significant) 
Table.2 Performance of different sources of livestock and poultry waste as organic manures on growth and yield of fodder maize

\begin{tabular}{|c|c|c|c|c|c|c|c|}
\hline & Treatments & $\begin{array}{l}\text { Plant dry } \\
\text { weight (g) } \\
20 \text { DAS }\end{array}$ & $\begin{array}{l}\text { Plant dry } \\
\text { weight (g) } \\
40 \text { DAS }\end{array}$ & $\begin{array}{l}\text { Plant dry } \\
\text { weight (g) } \\
60 \text { DAS }\end{array}$ & $\begin{array}{l}\text { Leaf Area } \\
\text { Index } \\
20 \text { DAS }\end{array}$ & $\begin{array}{l}\text { Leaf Area } \\
\text { Index } \\
40 \text { DAS }\end{array}$ & $\begin{array}{l}\text { Leaf Area } \\
\text { Index } \\
60 \text { DAS }\end{array}$ \\
\hline $\begin{array}{l}\mathbf{T} \\
1\end{array}$ & Control (RDF 80:40:30 Kg NPK ha ${ }^{-1}$ ) & 0.99 & 8.48 & 17.84 & 1.59 & 2.82 & 4.68 \\
\hline $\mathbf{T}$ & FYM $\left(16 \mathrm{t} \mathrm{ha}^{-1}\right)$ & 1.22 & 10.25 & 18.93 & 1.77 & 3.32 & 5.21 \\
\hline $\mathbf{T}$ & Vermicompost $\left(12 \mathrm{t} \mathrm{ha}^{-1}\right)$ & 1.58 & 10.38 & 22.78 & 1.78 & 3.34 & 5.39 \\
\hline $\begin{array}{l}\mathbf{T} \\
4\end{array}$ & Sheep Manure (12 $\left.\mathrm{t} \mathrm{ha}^{-1}\right)$ & 1.62 & 15.01 & 24.54 & 1.81 & 3.59 & 5.45 \\
\hline $\mathbf{T}$ & Poultry Manure (12 t ha $\left.{ }^{-1}\right)$ & 2.16 & 17.02 & 28.82 & 1.86 & 3.78 & 5.57 \\
\hline $\begin{array}{l}T \\
6\end{array}$ & $\begin{array}{c}\text { Fresh Bio-Slury \{Dung + Urine (1:1)\} Soil } \\
\text { Application } 20 \text { t ha }^{-1}\end{array}$ & 1.66 & 11.55 & 23.10 & 1.77 & 3.41 & 5.22 \\
\hline $\begin{array}{l}\text { T } \\
7\end{array}$ & $\begin{array}{c}\text { Fermented Bio-Slury }\{\text { Dung + Urine (1:1)\} } \\
\text { Soil Application } 20 \text { t ha }^{-1}\end{array}$ & 1.58 & 12.30 & 23.73 & 1.78 & 3.48 & 5.34 \\
\hline $\begin{array}{l}\mathbf{T} \\
8\end{array}$ & $\begin{array}{c}\text { Fresh Bio-Slury }\{\text { Dung + Urine }(1: 1)\} \text { Soil } \\
\text { Application } 20 \text { t ha }^{-1} \text { and Foliar Spray }(10 \%) \\
\text { @ 15, 30 \& } 45 \text { DAS }\end{array}$ & 1.89 & 13.82 & 23.96 & 1.80 & 3.55 & 5.53 \\
\hline $\begin{array}{l}\text { T } \\
9\end{array}$ & $\begin{array}{l}\text { Fermented Bio-Slury }\{\text { Dung + Urine (1:1)\} } \\
\text { Soil Application } 20 \mathrm{t} \mathrm{ha}^{-1} \text { and Foliar Spray } \\
(10 \%) @ 15,30 \text { \& } 45 \text { DAS }\end{array}$ & 1.90 & 15.33 & 24.26 & 1.84 & 3.82 & 5.56 \\
\hline & F-test & $\mathbf{S}$ & $\mathbf{S}$ & $\mathbf{S}$ & $\mathbf{S}$ & $\mathbf{S}$ & $\mathbf{S}$ \\
\hline & C.D. $(p=0.05)$ & 0.24 & 0.54 & 0.95 & 0.02 & 0.08 & 0.10 \\
\hline & CV (\%) & 8.65 & 2.48 & 2.39 & 1.15 & 1.28 & 1.13 \\
\hline & S.Ed. $( \pm)$ & 0.11 & 0.26 & 0.45 & 0.01 & $\mathbf{0 . 0 3}$ & 0.03 \\
\hline & $\operatorname{SEm}( \pm)$ & 0.08 & 0.18 & 0.32 & 0.01 & 0.04 & 0.05 \\
\hline
\end{tabular}

Note: S (Significant), NS (Non-Significant) 
Table.3 Performance of different sources of livestock and poultry waste as organic manures on growth and yield of fodder maize

\begin{tabular}{|c|c|c|c|c|c|c|}
\hline & Treatments & $\begin{array}{c}\text { CGR } \\
\left(\mathrm{g} / \mathrm{m}^{2} / \text { day }\right) \\
\text { 0-20 DAS }\end{array}$ & $\begin{array}{c}\text { CGR } \\
\left(\mathrm{g} / \mathrm{m}^{2} / \mathrm{day}\right) \\
20-40 \text { DAS }\end{array}$ & $\begin{array}{c}\text { CGR } \\
\left(\mathrm{g} / \mathrm{m}^{2} / \text { day }\right) \\
\text { 40-60 DAS }\end{array}$ & $\begin{array}{c}\text { RGR } \\
\left(\mathrm{gg}^{-1} \mathrm{day}^{-1}\right) \\
20-40 \text { DAS }\end{array}$ & $\begin{array}{c}\text { RGR } \\
\left(g^{-1} \text { day }^{-1}\right) \\
\text { 40-60 DAS }\end{array}$ \\
\hline $\mathbf{T}$ & Control (RDF 80:40:30 Kg NPK ha ${ }^{-1}$ ) & 0.0495 & 0.3745 & 0.4681 & 0.0465 & 0.0162 \\
\hline $\mathbf{T}$ & FYM $\left(16 \mathrm{t} \mathrm{ha}^{-1}\right)$ & 0.0610 & 0.4513 & 0.4311 & 0.0461 & 0.0132 \\
\hline $\begin{array}{l}\mathbf{T} \\
3\end{array}$ & Vermicompost $\left(12 \mathrm{tha}^{-1}\right)$ & 0.0791 & 0.440 & 0.6196 & 0.0408 & 0.0170 \\
\hline $\begin{array}{l}\mathbf{T} \\
4\end{array}$ & Sheep Manure (12 $\left.\mathrm{t} \mathrm{ha}^{-1}\right)$ & 0.0813 & 0.6691 & 0.4763 & 0.0482 & 0.0106 \\
\hline $\begin{array}{l}\mathbf{T} \\
5\end{array}$ & Poultry Manure (12 t ha ${ }^{-1}$ ) & 0.1078 & 0.7435 & 0.5898 & 0.0449 & 0.0122 \\
\hline $\begin{array}{l}T \\
6\end{array}$ & $\begin{array}{c}\text { Fresh Bio-Slury \{Dung + Urine (1:1)\} Soil } \\
\text { Application } 20 \text { t ha }^{-1}\end{array}$ & 0.0795 & 0.4980 & 0.5776 & 0.0430 & 0.0150 \\
\hline $\begin{array}{l}\text { T } \\
7\end{array}$ & $\begin{array}{c}\text { Fermented Bio-Slury }\{\text { Dung + Urine (1:1)\} Soil } \\
\text { Application } 20 \mathrm{t} \mathrm{ha}^{-1}\end{array}$ & 0.0793 & 0.5356 & 0.5713 & 0.0444 & 0.0142 \\
\hline $\begin{array}{l}\mathbf{T} \\
8\end{array}$ & $\begin{array}{c}\text { Fresh Bio-Slury }\{\text { Dung + Urine (1:1)\} Soil } \\
\text { Application } 20 \text { t ha }^{-1} \text { and Foliar Spray (10\%) @ 15, } \\
30 \& 45 \text { DAS }\end{array}$ & 0.0943 & 0.5971 & 0.5066 & 0.0432 & 0.0119 \\
\hline $\begin{array}{l}\text { T } \\
9\end{array}$ & $\begin{array}{l}\text { Fermented Bio-Slury }\{\text { Dung + Urine (1:1)\} Soil } \\
\text { Application } 20 \text { t ha }^{-1} \text { and Foliar Spray (10\%) @ 15, } \\
30 \& 45 \text { DAS }\end{array}$ & 0.0950 & 0.6713 & 0.4463 & 0.0456 & 0.0099 \\
\hline & F-test & $\mathbf{S}$ & $\mathbf{S}$ & $\mathbf{S}$ & $\mathbf{S}$ & $\mathbf{S}$ \\
\hline & C.D. $(p=0.05)$ & 0.01 & $\mathbf{0 . 0 3}$ & 0.05 & 0.003 & 0.002 \\
\hline & CV (\%) & 8.65 & 2.93 & 5.55 & 3.75 & 7.16 \\
\hline & S.Ed. $( \pm)$ & 0.01 & 0.01 & $\mathbf{0 . 0 2}$ & 0.001 & 0.001 \\
\hline & $\operatorname{SEm}( \pm)$ & $\mathbf{0 . 0 1}$ & $\mathbf{0 . 0 1}$ & $\mathbf{0 . 0 2}$ & 0.001 & 0.001 \\
\hline
\end{tabular}

Note: S (Significant), NS (Non-Significant) 
Table.4 Performance of different sources of livestock and poultry waste as organic manures on growth and yield of fodder maize

\begin{tabular}{|c|c|c|c|c|c|c|c|}
\hline & Treatments & $\begin{array}{l}\text { Stalk } \\
\text { Length }(\mathrm{cm}) \\
\text { 20DAS }\end{array}$ & $\begin{array}{l}\text { Stalk } \\
\text { Length } \\
(\mathrm{cm}) \\
40 \text { DAS }\end{array}$ & $\begin{array}{l}\text { Stalk } \\
\text { Length } \\
(\mathrm{cm}) \\
60 \text { DAS }\end{array}$ & $\begin{array}{l}\text { Stalk Girth } \\
\qquad(\mathrm{cm}) \\
20 \text { DAS }\end{array}$ & $\begin{array}{l}\text { Stalk Girth } \\
\qquad(\mathrm{cm}) \\
40 \text { DAS }\end{array}$ & $\begin{array}{l}\text { Stalk } \\
\text { Girth }(\mathbf{c m}) \\
60 \text { DAS }\end{array}$ \\
\hline $\begin{array}{l}\mathbf{T} \\
1\end{array}$ & Control (RDF 80:40:30 Kg NPK ha ${ }^{-1}$ ) & 8.18 & 46.83 & 84.70 & 3.16 & 6.63 & 8.53 \\
\hline $\mathbf{T}$ & FYM $\left(16 \mathbf{t ~ h a}^{-1}\right)$ & 9.23 & 56.50 & 96.84 & 3.76 & 8.10 & 10.20 \\
\hline $\mathbf{T}$ & Vermicompost (12 t ha $\left.{ }^{-1}\right)$ & 9.35 & 60.67 & 102.40 & 3.90 & 8.23 & 10.63 \\
\hline T & Sheep Manure (12 t ha ${ }^{-1}$ ) & 9.71 & 68.17 & 115.12 & 4.21 & 9.08 & 12.08 \\
\hline $\mathbf{T}$ & Poultry Manure (12 $\mathrm{t} \mathrm{ha}^{-1}$ ) & 11.53 & 79.50 & 140.66 & 4.88 & 9.87 & 13.47 \\
\hline $\begin{array}{l}T \\
6\end{array}$ & $\begin{array}{c}\text { Fresh Bio-Slury \{Dung + Urine (1:1)\} Soil } \\
\text { Application } 20 \mathrm{t} \mathrm{ha}^{-1}\end{array}$ & 9.93 & 68.87 & 110.95 & 4.03 & 8.08 & 10.58 \\
\hline $\begin{array}{l}\text { T } \\
7\end{array}$ & $\begin{array}{c}\text { Fermented Bio-Slury }\{\text { Dung + Urine (1:1)\} } \\
\text { Soil Application } 20 \mathrm{t} \mathrm{ha}^{-1}\end{array}$ & 9.46 & 67.17 & 110.85 & 4.13 & 8.37 & 11.07 \\
\hline $\begin{array}{l}\mathbf{T} \\
8\end{array}$ & $\begin{array}{c}\text { Fresh Bio-Slury }\{\text { Dung }+ \text { Urine }(1: 1)\} \text { Soil } \\
\text { Application } 20 \mathrm{t} \mathrm{ha}^{-1} \text { and Foliar Spray } \\
(10 \%) @ 15,30 \text { \& 45 DAS }\end{array}$ & 10.05 & 68.50 & 114.21 & 4.58 & 8.73 & 11.63 \\
\hline $\begin{array}{l}\mathbf{T} \\
9\end{array}$ & $\begin{array}{l}\text { Fermented Bio-Slury }\{\text { Dung + Urine (1:1)\} } \\
\text { Soil Application } 20 \mathrm{t} \mathrm{ha}^{-1} \text { and Foliar Spray } \\
(\mathbf{1 0 \% )} @ 15,30 \text { \& } 45 \text { DAS }\end{array}$ & 10.95 & 75.50 & 128.33 & 4.80 & 9.17 & 12.47 \\
\hline & F-test & $\mathbf{S}$ & $\mathbf{S}$ & $\mathbf{S}$ & $\mathbf{S}$ & $\mathbf{S}$ & $\mathbf{S}$ \\
\hline & C.D. $(p=0.05)$ & 1.48 & 4.36 & 4.36 & 0.49 & 0.39 & 0.39 \\
\hline & CV $(\%)$ & 8.68 & 3.84 & 2.26 & 6.77 & 2.66 & 2.02 \\
\hline & S.Ed. $( \pm)$ & 0.70 & 2.06 & 2.06 & 0.23 & 0.18 & 0.18 \\
\hline & $\operatorname{SEm}( \pm)$ & 0.49 & 1.46 & 1.46 & 0.16 & 0.13 & 0.13 \\
\hline
\end{tabular}

Note: S (Significant), NS (Non-Significant) 
Table.5 Performance of different sources of livestock and poultry waste as organic manures on growth and yield of fodder maize

\begin{tabular}{|c|c|c|c|c|c|c|c|c|}
\hline & Treatments & $\begin{array}{l}\text { No. of days } \\
\text { to }(50 \%) \\
\text { Tasseling }\end{array}$ & $\begin{array}{l}\text { No. of } \\
\text { Cobs } \\
\text { plant }^{-1}\end{array}$ & $\begin{array}{l}\text { Cob } \\
\text { Length } \\
\text { (cm) }\end{array}$ & $\begin{array}{l}\text { Cob Girth } \\
\quad(\mathrm{cm})\end{array}$ & $\begin{array}{l}\text { Cob weight } \\
\text { plant }^{-1}(g)\end{array}$ & $\begin{array}{c}\text { Cob } \\
\text { weight } \\
\text { per } \mathbf{~ m}^{2}(g)\end{array}$ & $\begin{array}{c}\text { Cob } \\
\text { weight } \\
\left(t \text { ha }^{-1}\right)\end{array}$ \\
\hline $\begin{array}{l}\mathbf{T} \\
1\end{array}$ & Control (RDF 80:40:30 Kg NPK ha ${ }^{-1}$ ) & 65.66 & 1.00 & 15.31 & 10.81 & 45.12 & 721.86 & 7.21 \\
\hline $\mathbf{T}$ & FYM $\left(16 \mathrm{t} \mathrm{ha}^{-1}\right)$ & 64.00 & 1.33 & 15.53 & 12.55 & 48.28 & 1030.45 & 10.29 \\
\hline $\mathbf{T}$ & Vermicompost (12 $\left.\mathrm{t} \mathrm{ha}^{-1}\right)$ & 61.33 & 1.50 & 15.44 & 13.43 & 55.30 & 1327.2 & 13.27 \\
\hline $\begin{array}{l}\mathbf{T} \\
4\end{array}$ & Sheep Manure (12 t ha $\left.{ }^{-1}\right)$ & 58.33 & 2.17 & 15.55 & 14.98 & 74.62 & 2583.70 & 25.83 \\
\hline $\mathbf{T}$ & Poultry Manure (12 t ha $\left.{ }^{-1}\right)$ & 55.66 & 2.33 & 16.35 & 15.52 & 85.35 & 3175.52 & 31.89 \\
\hline $\begin{array}{l}\text { T } \\
6\end{array}$ & $\begin{array}{c}\text { Fresh Bio-Slury \{Dung + Urine (1:1)\} Soil } \\
\text { Application } 20 \mathrm{t} \mathrm{ha}^{-1}\end{array}$ & 63.33 & 1.67 & 15.83 & 13.74 & 57.14 & 1518.48 & 15.18 \\
\hline $\begin{array}{l}\text { T } \\
7\end{array}$ & $\begin{array}{c}\text { Fermented Bio-Slury }\{\text { Dung + Urine (1:1)\} } \\
\text { Soil Application } 20 \text { t ha }^{-1}\end{array}$ & 57.66 & 1.67 & 15.50 & 14.00 & 62.50 & 1666.40 & 16.65 \\
\hline $\begin{array}{l}\mathbf{T} \\
8\end{array}$ & $\begin{array}{c}\text { Fresh Bio-Slury }\{\text { Dung }+ \text { Urine }(1: 1)\} \text { Soil } \\
\text { Application } 20 \text { t ha }^{-1} \text { and Foliar Spray } \\
(10 \%) @ 15,30 \& 45 \text { DAS }\end{array}$ & 60.00 & 1.83 & 15.40 & 14.07 & 65.43 & 1919.73 & 19.19 \\
\hline $\begin{array}{l}\mathbf{T} \\
9\end{array}$ & $\begin{array}{l}\text { Fermented Bio-Slury }\{\text { Dung + Urine (1:1)\} } \\
\text { Soil Application } 20 \mathrm{t} \mathrm{ha}^{-1} \text { and Foliar Spray } \\
(10 \%) @ 15,30 \& 45 \text { DAS }\end{array}$ & 57.33 & 2.17 & 15.72 & 14.81 & 71.81 & 2489.09 & 24.88 \\
\hline & F-test & $\mathbf{S}$ & $\mathbf{S}$ & NS & $\mathbf{S}$ & $\mathbf{S}$ & $\mathbf{S}$ & $\mathbf{S}$ \\
\hline & C.D. $(p=0.05)$ & 1.97 & 0.39 & 0.70 & 0.69 & 3.52 & 374.18 & 3.74 \\
\hline & CV (\%) & 1.89 & 12.96 & 2.57 & 2.91 & 3.24 & 11.84 & 11.85 \\
\hline & S.Ed. $( \pm)$ & 0.93 & 0.18 & 0.33 & 0.33 & 1.66 & 176.51 & 1.77 \\
\hline & $\operatorname{SEm}( \pm)$ & 0.66 & 0.13 & 0.23 & 0.23 & 1.17 & 124.81 & 1.25 \\
\hline
\end{tabular}

Note: S (Significant), NS (Non-Significant) 
Table.6 Performance of different sources of livestock and poultry waste as organic manures on growth and yield of fodder maize

\begin{tabular}{|c|c|c|c|c|c|c|c|}
\hline & Treatments & $\begin{array}{l}\text { Green } \\
\text { Fodder } \\
\text { Yield Plant } \\
\text { (g) }\end{array}$ & $\begin{array}{c}\text { Green } \\
\text { Fodder } \\
\text { Yield Per } \mathbf{m}^{2} \\
\text { (g) }\end{array}$ & $\begin{array}{c}\text { Green } \\
\text { Fodder } \\
\text { Yield }\left(\mathrm{t} \mathrm{ha}^{-1}\right)\end{array}$ & $\begin{array}{l}\text { Dry Fodder } \\
\text { Yield Plant } \\
\quad \text { (g) }\end{array}$ & $\begin{array}{l}\text { Dry } \\
\text { Fodder } \\
\text { Yield Per } \\
\text { m }^{2}(\mathrm{~g})\end{array}$ & $\begin{array}{l}\text { Dry Fodder } \\
\text { Yield } \\
\left(\mathrm{t} \mathrm{ha}^{-1}\right)\end{array}$ \\
\hline $\begin{array}{l}\mathbf{T} \\
1\end{array}$ & Control (RDF 80:40:30 Kg NPK ha ${ }^{-1}$ ) & 135.81 & 2173.06 & 21.730 & 26.52 & 424.37 & 4.24 \\
\hline $\begin{array}{l}\mathbf{T} \\
2\end{array}$ & FYM $\left(16\right.$ t ha $\left.^{-1}\right)$ & 147.17 & 2354.72 & 23.547 & 27.85 & 445.70 & 4.46 \\
\hline $\mathbf{T}$ & Vermicompost (12 t ha $\left.{ }^{-1}\right)$ & 147.92 & 2366.77 & 23.677 & 32.14 & 514.24 & 5.14 \\
\hline T & Sheep Manure (12 t ha ${ }^{-1}$ ) & 165.07 & 2641.06 & 26.410 & 36.22 & 581.44 & 5.18 \\
\hline $\begin{array}{l}\mathbf{T} \\
5\end{array}$ & Poultry Manure (12 t ha $\left.{ }^{-1}\right)$ & 195.75 & 3132.05 & 31.320 & 41.22 & 659.57 & 6.60 \\
\hline $\begin{array}{l}T \\
6\end{array}$ & $\begin{array}{c}\text { Fresh Bio-Slury }\{\text { Dung }+ \text { Urine }(1: 1)\} \text { Soil } \\
\text { Application } 20 \mathrm{t} \mathrm{ha}^{-1}\end{array}$ & 148.37 & 2373.97 & 23.739 & 32.63 & 522.08 & 5.22 \\
\hline $\begin{array}{l}\text { T } \\
7\end{array}$ & $\begin{array}{c}\text { Fermented Bio-Slury }\{\text { Dung + Urine (1:1)\} } \\
\text { Soil Application } 20 \text { t ha }^{-1}\end{array}$ & 151.59 & 2425.49 & 24.254 & 33.44 & 535.04 & 5.35 \\
\hline $\begin{array}{l}\mathbf{T} \\
8\end{array}$ & $\begin{array}{c}\text { Fresh Bio-Slury }\{\text { Dung + Urine }(1: 1)\} \text { Soil } \\
\text { Application } 20 \text { t ha }^{-1} \text { and Foliar Spray } \\
(10 \%) @ 15,30 \& 45 \text { DAS }\end{array}$ & 155.17 & 2482.77 & 24.827 & 35.38 & 566.18 & 5.66 \\
\hline $\begin{array}{l}\text { T } \\
9\end{array}$ & $\begin{array}{l}\text { Fermented Bio-Slury }\{\text { Dung + Urine (1:1)\} } \\
\text { Soil Application } 20 \mathrm{t} \mathrm{ha}^{-1} \text { and Foliar Spray } \\
\text { (10\%)@ 15, 30 \& } 45 \text { DAS }\end{array}$ & 162.17 & 2594.72 & 25.947 & 35.80 & 572.90 & 5.73 \\
\hline & F-test & $\mathbf{S}$ & $\mathbf{S}$ & $\mathbf{S}$ & $\mathbf{S}$ & $\mathbf{S}$ & $\mathbf{S}$ \\
\hline & C.D. $(p=0.05)$ & 15.08 & 241.22 & 2.41 & 0.89 & 14.29 & 0.14 \\
\hline & CV $(\%)$ & 5.56 & 5.56 & 5.56 & 1.54 & 1.54 & 1.54 \\
\hline & S.Ed. $( \pm)$ & 7.11 & 113.79 & 1.14 & 0.42 & 6.74 & 0.07 \\
\hline & $\operatorname{SEm}( \pm)$ & 5.03 & 80.46 & 0.80 & 0.30 & 4.77 & 0.05 \\
\hline
\end{tabular}

Note: S (Significant), NS (Non-Significant) 
Fig.1 Performance of different sources of livestock and poultry waste as organic manures on growth and yield of fodder maize

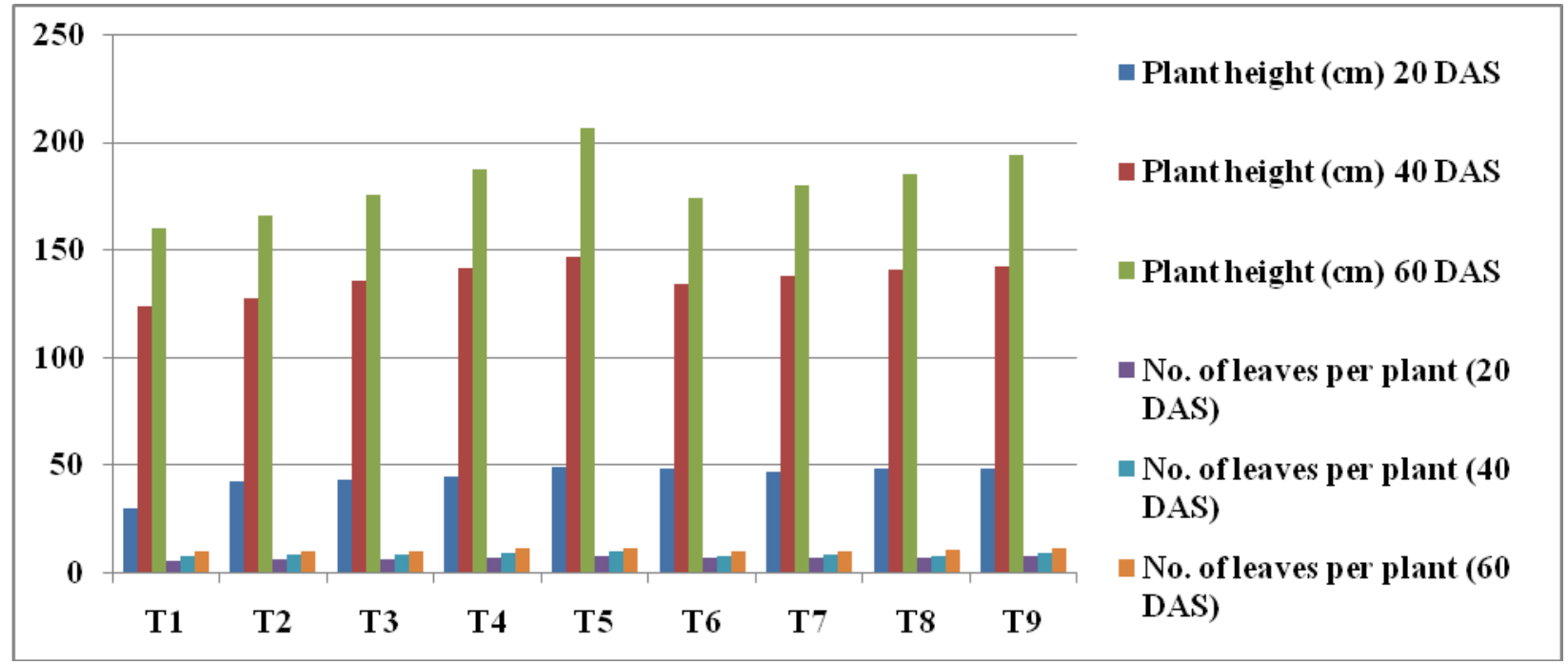

Fig.2 Performance of different sources of livestock and poultry waste as organic manures on growth and yield of fodder maize

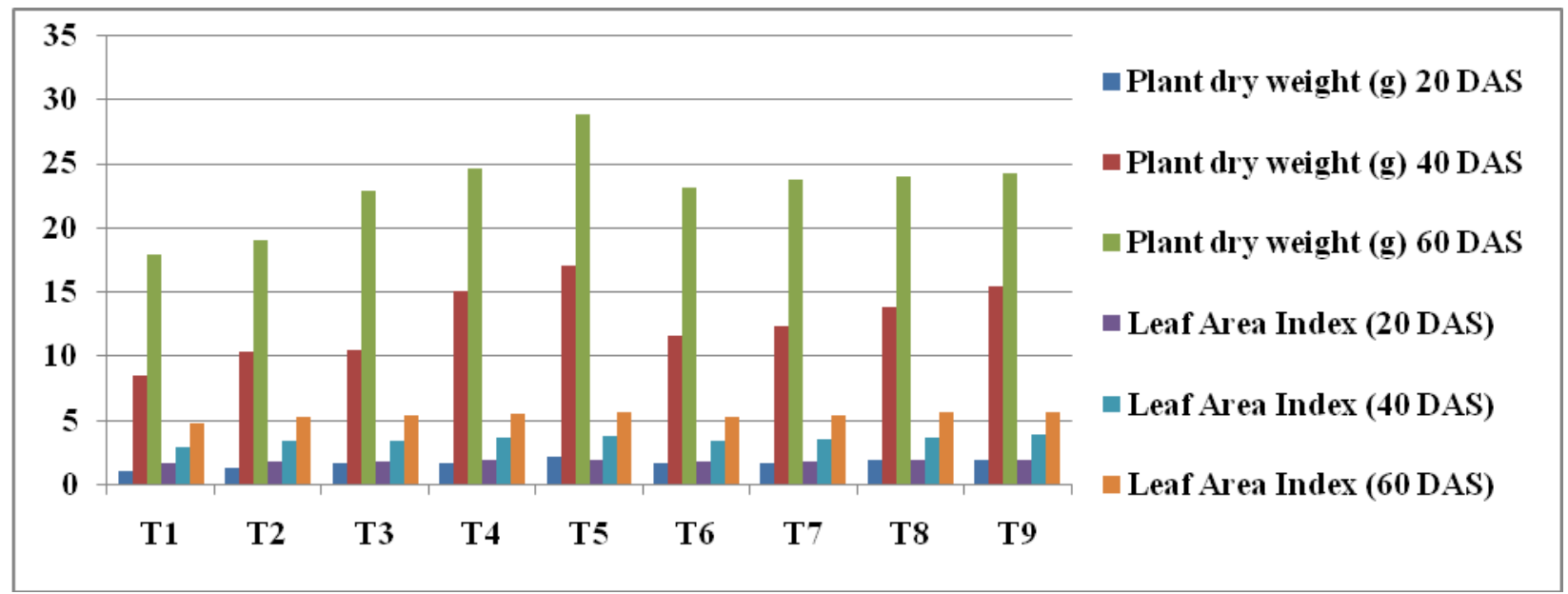


Fig.3 Performance of Different Sources of Livestock and Poultry Waste as Organic Manures on Growth and Yield of Fodder Maize

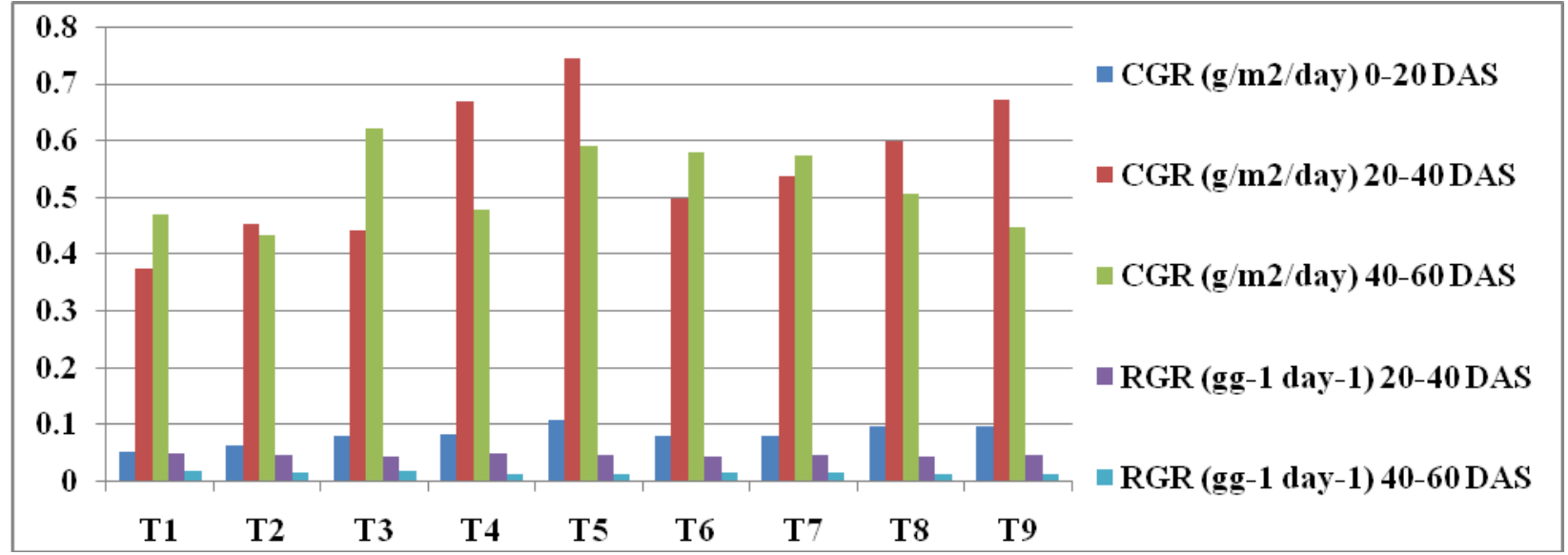

Fig.4 Performance of Different Sources of Livestock and Poultry Waste as Organic Manures on Growth and Yield of Fodder Maize

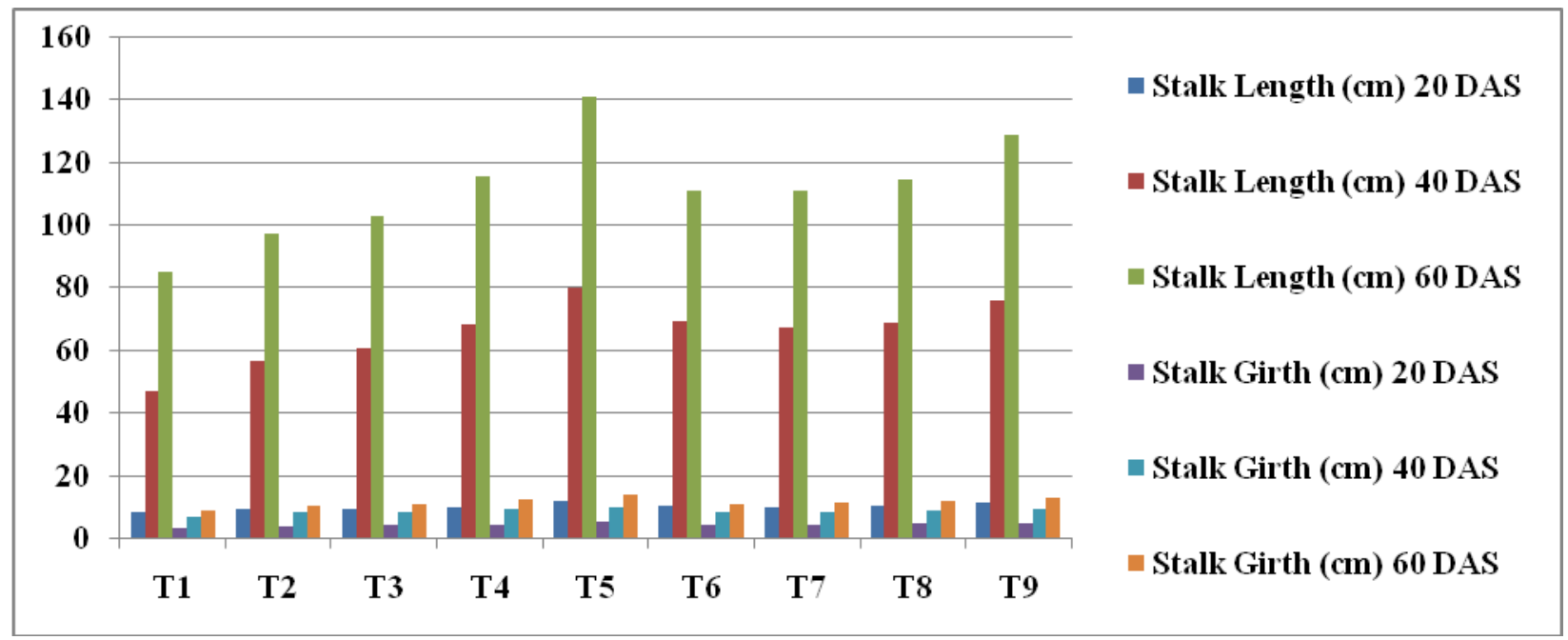


Fig.5 Performance of Different Sources of Livestock and Poultry Waste as Organic Manures on Growth and Yield of Fodder Maize

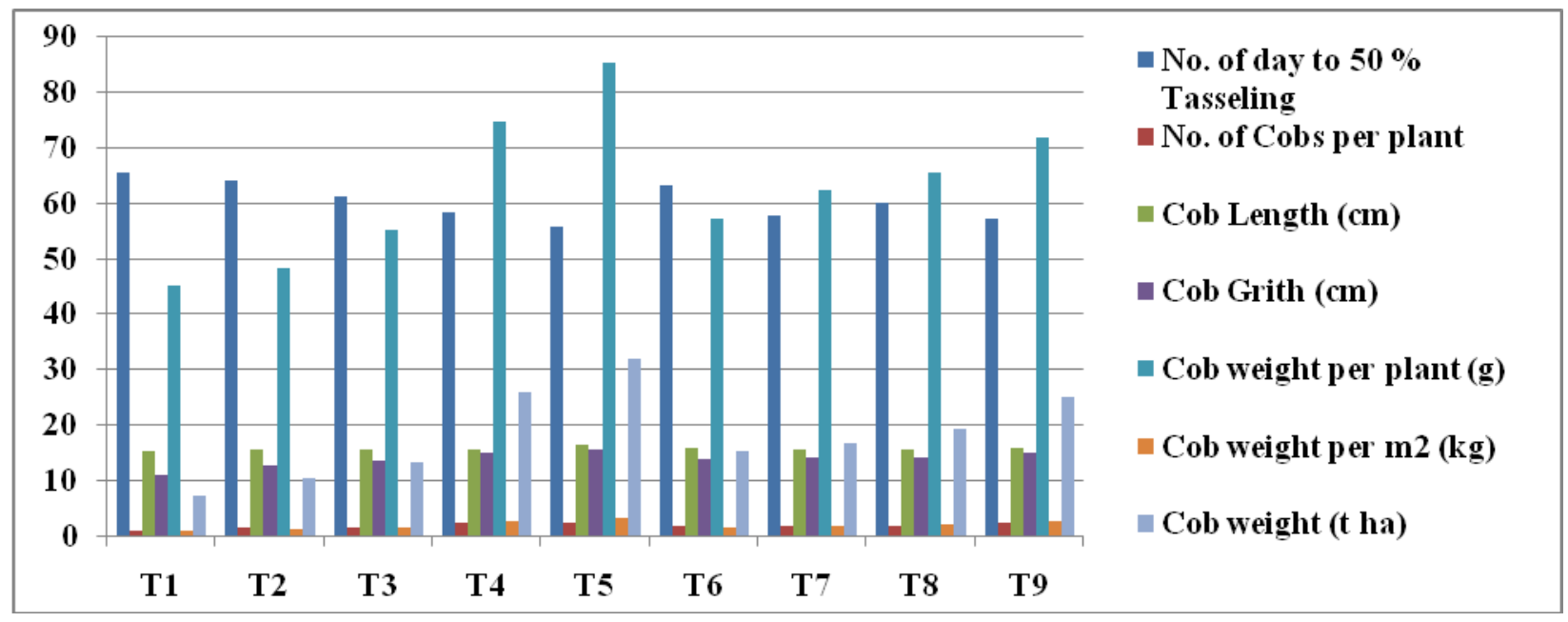

Fig.6 Performance of Different Sources of Livestock and Poultry Waste as Organic Manures on Growth and Yield of Fodder Maize

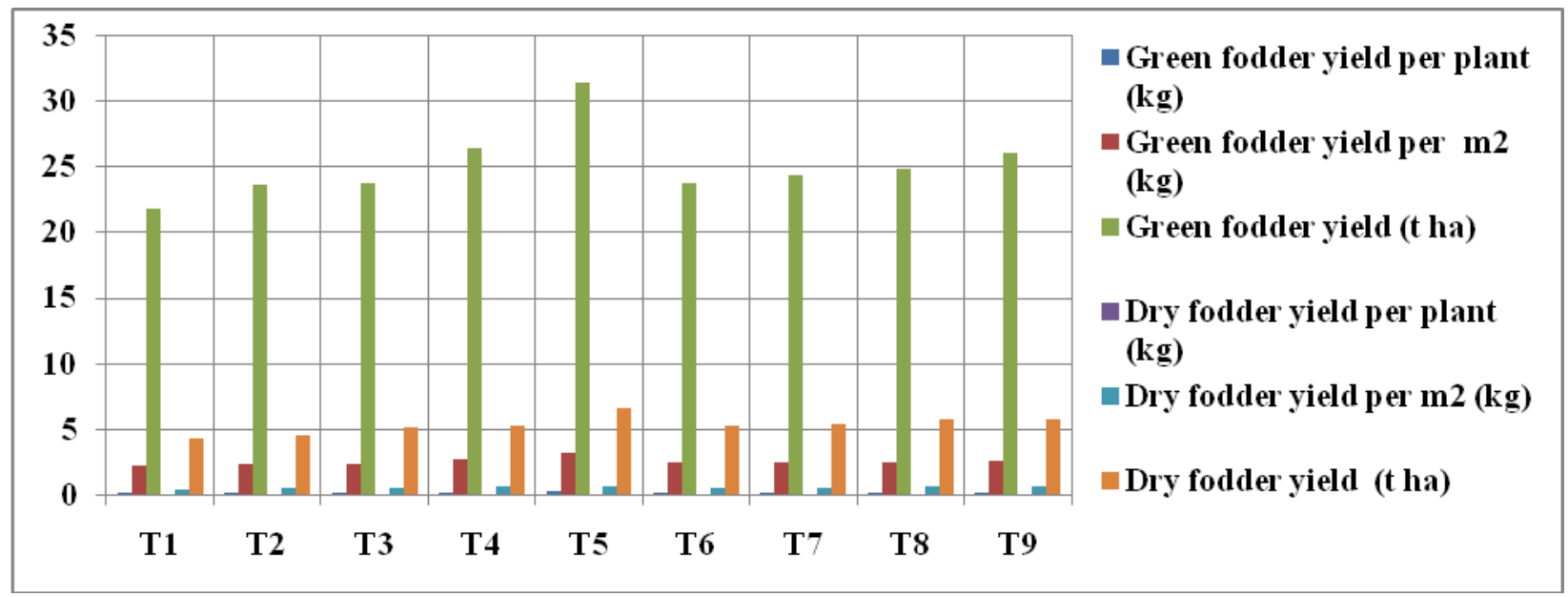

The green forage yield of other treatments was intermediated. These results are quite in line with the Ayub et al., (2002), who reported that Nitrogen and Phosphorus produced significantly higher fodder yield of maize than control. Devi 2002 also reported that fodder maize variety "African Tall" produced significantly higher green fodder yield at higher dose of nitrogen while bio fertilizers produced lower yield.

Green fodder yield increased significantly upto $120 \mathrm{~kg} \mathrm{~N} \mathrm{ha}^{-1}$. In contrast with Reiad et al., (1992) and Lakoo et al., (2004) the organic manures and inorganic fertilizer increases the maize fodder yield.The reason 
behind the higher yield attributes recorded might be also due to higher availability of NPK which was directly related to the vegetative and reproductive phases of the crop and attributes complex phenomenon of phosphorus utilization in plant metabolism. It also helped in the efficient absorption and utilization of the other required plant nutrients which ultimately increased the yield Girma $e t$ al., (2006) and Parvez et al., (2009). Similar findings are reported by Singh and Khan 2003. Statistically the maximum crude fibre $(37.00 \%)$ was observed in $\mathrm{T}_{2} \quad(\mathrm{~N}$ : $\mathrm{P}_{2} \mathrm{O}_{5}$ 150:60 kg ha ${ }^{-1}$ ) followed by $\mathrm{T}_{3}$ (FYM $\left.4000 \mathrm{~kg} \mathrm{ha}^{-1}\right), \mathrm{T}_{4}\left(\mathrm{PM} 3000 \mathrm{~kg} \mathrm{ha}^{-1}\right), \mathrm{T}_{5}$ $\left(\mathrm{N}: \mathrm{P}_{2} \mathrm{O}_{5} 112: 45+\mathrm{PM} 750 \mathrm{kgha}^{-1}\right)$ and $\mathrm{T}_{6}(\mathrm{~N}:$ $\mathrm{P}_{2} \mathrm{O}_{5}$ 112:45+ FYM $1000 \mathrm{~kg} \mathrm{ha}^{-1}$ ) produced crude fibre $\%$ of $34.83,34.83,35.24$ and 35.2, respectively and were statistically same with each other Ahmad et al., (2011). The similar findings are confirmed by Rafiq et al., (1996) who checked the effect of nitrogen application on growth, green fodder yield and quality of maize cv. Neelum. Similarly, Safdar (1997) also reported that green fodder yield; protein, fiber and total ash contents were increased with nitrogen rates in maize and in the same way Tariq (1998) also reported that in fodder maize, by increasing nitrogen levels;crude protein, crude fiber and ashcontents were increased. Maria et al., 2014 the bio-slurry contains higher amount of phosphorus, potassium, zinc, iron, manganese and copper, which is limited factor in many soils. Bioslurry with the dose of 10 to 20 tons $\mathrm{ha}^{-1}$ in irrigated areas and 5 to 10 tons $\mathrm{ha}^{-1}$ in rainfed crops can show significant increase in yields. Indeed, bio-slurry increases crop revenues by $25 \%$ on average. Similarly, Gurung 1997 reported that bio-slurry also contains higher amount of nutrients like NPK and micro nutrients along with beneficial microorganism, which helps in conversion of non-available form to available form. He also reported that application of biogas slurry @ of $10 \mathrm{t} \mathrm{ha}^{-1}$ in potato, tomato, brinjal, groundnut, jowar, maize, and okra gave better yields than FYM. Sarkar et al., (2017) the highest grain yield $\left(8882.3 \mathrm{~kg} \mathrm{ha}^{-1}\right)$ was obtained in the treatment (4 ton Co-digested Bio-Slurry $+75 \mathrm{~kg} \mathrm{~N}+60$ $\mathrm{kg} \mathrm{p} \mathrm{ha}{ }^{-1}$ ) and the lowest grain yield (2643.5 $\mathrm{kg} \mathrm{ha}^{-1}$ ) was recorded in the control. Four ton Co-digested Bio-Slurry added with $75 \mathrm{~kg} \mathrm{~N}+$ $60 \mathrm{~kg} \mathrm{p} \mathrm{ha}{ }^{-1}$ was found to be the most profitable and cost effective treatment combination.

It could be concluded that by using Poultry Manure (12 $\left.\mathrm{tha}^{-1}\right)$ followed by Sheep Manure $\left(12 \mathrm{t} \mathrm{ha}^{-1}\right)$ higher yield can be obtained as compared to control (RDF). Whereas, Fermented Bio-Slury \{Dung + Urine (1:1) \} Soil Application $20 \mathrm{t} \mathrm{ha}^{-1}$ and Foliar Spray (10\%) @ 15, 30 and 45 DAS was significantly at par for obtaining higher yield attributes namely; number of cobs plant ${ }^{-1}$, cob girth $(\mathrm{cm})$, cob weight plant ${ }^{-1}$, cob yield $\left(\mathrm{t} \mathrm{ha}^{-1}\right)$, green fodder yield $\left(\mathrm{t} \mathrm{ha}^{-1}\right)$ and dry fodder yield $\left(\mathrm{t} \mathrm{ha}{ }^{-1}\right)$. Most of our farmers are involved in animal husbandry activities; fodder based enterprises could be a sustainable for income generation.

Greater attention may be paid towards increasing the net returns per unit area by reducing the input cost on chemical fertilizers by replacing them with organic manures and livestock waste utilization in fodder production, which plays a promising approach towards doubling the farm income of small and marginal farmers. Since the findings are based on the research done in one season, for further validation multi-location trial could be carried out.

\section{Acknowledgement}

The authors acknowledge, Dean Veterinary College, Bidar, Karnataka, India for providing financial support to carry out the research work. 


\section{References}

A.H. Ahmad, A. Wahid, F. Khalid, N.Fiaz and M.S.I. Zamir. 2011. Impact of Orgaini and Inorganic Sources of Nitrogen and Phosphorus Fertilizers on Growth, Yield and Quality of Forrage Oat (Avena sativa L.). Cercetari Agronomice in Moldova, 14(3):39-49.

Abid Hussain, Subhanullah, Mukhtiar Ali, Waqar Ali, Muhammad Tariq, Shabir Muhammad, Mussadiq Khan Khalil and Muhammad Owais Khan 2018. Impression of Disparate Levels of Poultry Manure and Humic Acid on the Yield and Yield Traits of Maize (Zea mays L.). European Journal of Experimental Biology, Vol.8 No.4:23.

Abubakar, Z. A. and Ali, A. D 2018.Screening effect of organic manure on the vegetative growth of maize (Zea mays L.). Journal of Bioscience and Agriculture Research, Vol. 16, Issue 02: 1356-1364.

Adeli A, Sistani KR, Rowe DE, Tewolde H 2007. Effects of broiler litter applied to no-till and tillage cotton on selected soil properties. Soil Sci Soc Am. J, 71: 974-983.

Ayub M., M.A. Nadeem, M.S. Sharar, N. Mahmood, 2002. Response of maize (Zea mays L.) fodder to different levels of nitrogen and phosphorus. Asian $\mathrm{J}$ of plant Sci 4(1): 352-354.

Badu AB, Fakorede MAB, Menkir A, Sanogo D. Editors (2012). Conduct and management of maize field trials. IITA, Ibadan, Nigeria: 59 pp.

Boote K. J. J. W Jones, G. Horgenboom, 1988 Research and management application of pnutgro crop growth model proc. Am. Peanut Res. Edu. Soc., 20, 57.

Chandrashekara, S. I., Harlapur, S., Muralikrishan and Girijesh, G. K 2000. Response of maize to organic manures with inorganic fertilizers. Karnataka
Journal of Agricultural Sciences, 13: 144-146.

Devi L.G., 2002 - Forage yield of maize (Zea mays L.) as influenced by nitrogen levels and biofertilizers. ForageResearch, 27(4): 263-266.

Enoch H. Z., R. G Hurd, (1979). The effect of elevated $\mathrm{CO}_{2}$ concatenation in the atmosphere in plant transpiration and water use efficiency: A study with potted carnation plants. Int. J. Biometer. 23, 343-351.

Girma, K., B. Raun, H. Zhang and J. Mosali. 2006. What about foliar $\mathrm{p}$ on corn $\&$ winter wheat? Fluid J, 14(3): 17-19.

GOI 2019. (Department of Animal Husbandry \& Dairying, Ministry of Fisheries, Animal Husbandry \& Dairying).

Gonzalez, D.R, Alvarez and J. Matheus 2001. Comparison of three organic fertilizers for the production of sweet corn (Zea mays Saccharata). Proceedings of the Inter American Society for Tropical Horticulture, 45: 106-109.

Gurung. B. 1997. Review of Literature on effect of slurry use on crop production. Nepal.

Hirzel J, Walter I, Undurraga P, Cartagena M 2007. Residual effects of poultry litter on silage maize (Zea mays L.) growth and soil properties derived from volcanic ash. Soil Sci Plant Nutr, 53: 480-488.

Johnson, R. R. 2008. Growth \& yield of maize as affected by early season defoliation. Agronomy J. 70, 995-998.

Kingery WL, Wood CW, Delaney DP, Williams JC, Mullins GL, Van Santen E 1993. Implications of long-term application of poultry litter on tall fescue pastures. J Prod Agric, 63: 390395.

Lakoo A.A., F.C. Oad, A.A. Solangi, M.H. Siddiqui 2004. Economics of maize fodder under organic and inorganic 
fertilizers. Int J Agric Biol, 6(6): 11721173.

Lavinia Maria E. Warnars, Hivos 2014.Bioslurry: A supreme fertiliser. Practitioners Track, IFOAM Organic World Congress. 'Building Organic Bridges', 13-15 Oct., Istanbul, Turkey.

Lavinia Warnars Harrie Oppenoorth 2014. Bio-slury: A Supereme Fertilizer-A Study on bio-slurry results and uses, ISBN/EAN 978-90-70435-07-3: 1-52.

Leith J. H., J. P. Reynolds, H. H. Rogers, (1986). Estimation of Leaf Area of soybeans grown under elevated carbon dioxide levels field crops Res., 13, 193-203.

Liu WK, Du LF and Yang QC 2008. Biogas slurry added amino acids decreased nitrate concentrations of lettuce in sand culture. Acta Agriculture Scandinavia, Section B-Soil and Plant Science, 58: 1-5.

Materechera S.A, and A.M. Salagae, 2002. Use of Partially-decomposed cattle and chicken manure amended with wood ash in two South African arable soils with contrasting texture: effect on Nutrient uptake, early growth and dry matter yield of maize. Communications in Soil Science and Plant Analysis, 33, (2):179-201.

Michael, S. and George, R 2008. Fertilizing Crop land with poultry manure. University of Minnesota Extension Service. Minnesota agricultural Service Unpublished article.

Mohd Zakir Hussain, Mritunjay Kumar, Devendra Singh and Shashidhar Yadav 2019. Effect of Different Levels of Potassium on Yield and Yield Attributes of Kharif Maize (Zea mays L.). Int. J. Curr. Microbiol. App. Sci, 8(1): 2054-2060.

Mosquera MEL, Cabaleiro F, Sainz MJ, Fabal AL, Carral E 2008. Fertilizing value of broiler litter: effects of drying and pelletizing. Bio resource Technol, 99: 5626-5633.

Moss BR, Reeves DW, Lin JC, Torbert HA, Mc Elhenney WH, Mask P, Kezar W 2001. Yield and quality of three corn hybrids as affected by broiler litter fertilization and crop maturity. Anim Feed Sci Tech, 94: 43-56.

Nawab, K., Shah, P., Arif, M., Khan, M. And Ali, K. 2011. Effect of cropping patterns, FYM, $\mathrm{K}$ and $\mathrm{Zn}$ of wheat growth and grain yield. Sarhad Journal of Agriculture, 27(3):371- 375.

Parvez, K., M.Y. Memon, M. Imtiaz and M. Aslam. 2009. Response of wheat to foliar and soil application of urea at different growth stages. Pakistan Journal of Botany 41: 1197-1204.

Rafiq M., J.K. Jadoon, K. Mahmood, M.A. Naqvi 1996. Economic benefits of supplementing lambs with urea molasses blocks on ranges of Pakistan. Asian-Aust. J. Anim. Sci, 3: 127-132.

Rakesh Kumar 2016. Fodder Production Status, Constraints, Strategies. Biotech Articles.

Reiad M.S., E.L. Hakeem, M.A. Hammada, S.O.M. Abd-Alla, 1992 - Fodder sorghum yield and its components as affected by nitrogen and organic manure fertilization rates under Siwa Oasis conditions. Annals of Agric Sci Moshtohor 33(2): 613-622.

Safdar Z 1997. Optimization of nitrogen and its effect on yield and quality of maize fodder. MSc. (Hons.) Agri. Thesis, Dept. of Agron., Univ. Of Agric., Faisalabad, Pakistan.

Sarannappa 2002. Integrated nutrient supply for enhancing crop productivity and sustaining soil fertility. Second International Agronomy Congress in Balancing food and environmental security. A continuous challenge. Vol. 1. 26-30, New Delhi, India. pp. 335336. 
Singh, R. and Khan, M. A. (2003). Response of clusterbean (Cyamopsis tetragonoloba L.) varieties to fertility levels and cropping systems under arid condition. Advances in arid legume research. 225-228.

SK. Sarkar and MK Uddin 2017. Integrated Effects of Nitrogen, Phosphorus and Co-Digested Bioslury on Growth and Yield of Zea mays L. Bangladesh J. Bot, 46(4): 1397-1406.

Sunil Kumar, Agrawal, R.K., Dixit, A. K., Rai, Arvind K. and Rai, S. K. 2012. Forage Crops and Their Management.
Indian Grassland and Fodder Research Institute, Jhansi-Uttar Pradesh, India. pp 60.

Tariq. M 1988.Fodder yield and quality of two maize varieties at different nitrogen levels. MSc Thesis Dept. Agron. Univ. Agric. of Faisalabad.

Warnars, L. 2013. Bio-slurry: the new brown gold? Bio-slurry manual; Hivos.

Warnars, P 2012. From Biomass to Biogas: Present day status \& future Requirements. Master ThesisInternational Development Studies, Utrecht University, p. 64.

\section{How to cite this article:}

Prasad Mithare, U.S. Biradar, Pratik Jawarkar, M. Vaishali, Saste Ashwini, Kamlakar and Avinash Karbari. 2019. Performance of Different Sources of Livestock and Poultry Waste as Organic Manures on Growth and Yield of Fodder Maize (Zea mays). Int.J.Curr.Microbiol.App.Sci. 8(11): 2275-2294. doi: https://doi.org/10.20546/ijcmas.2019.811.265 